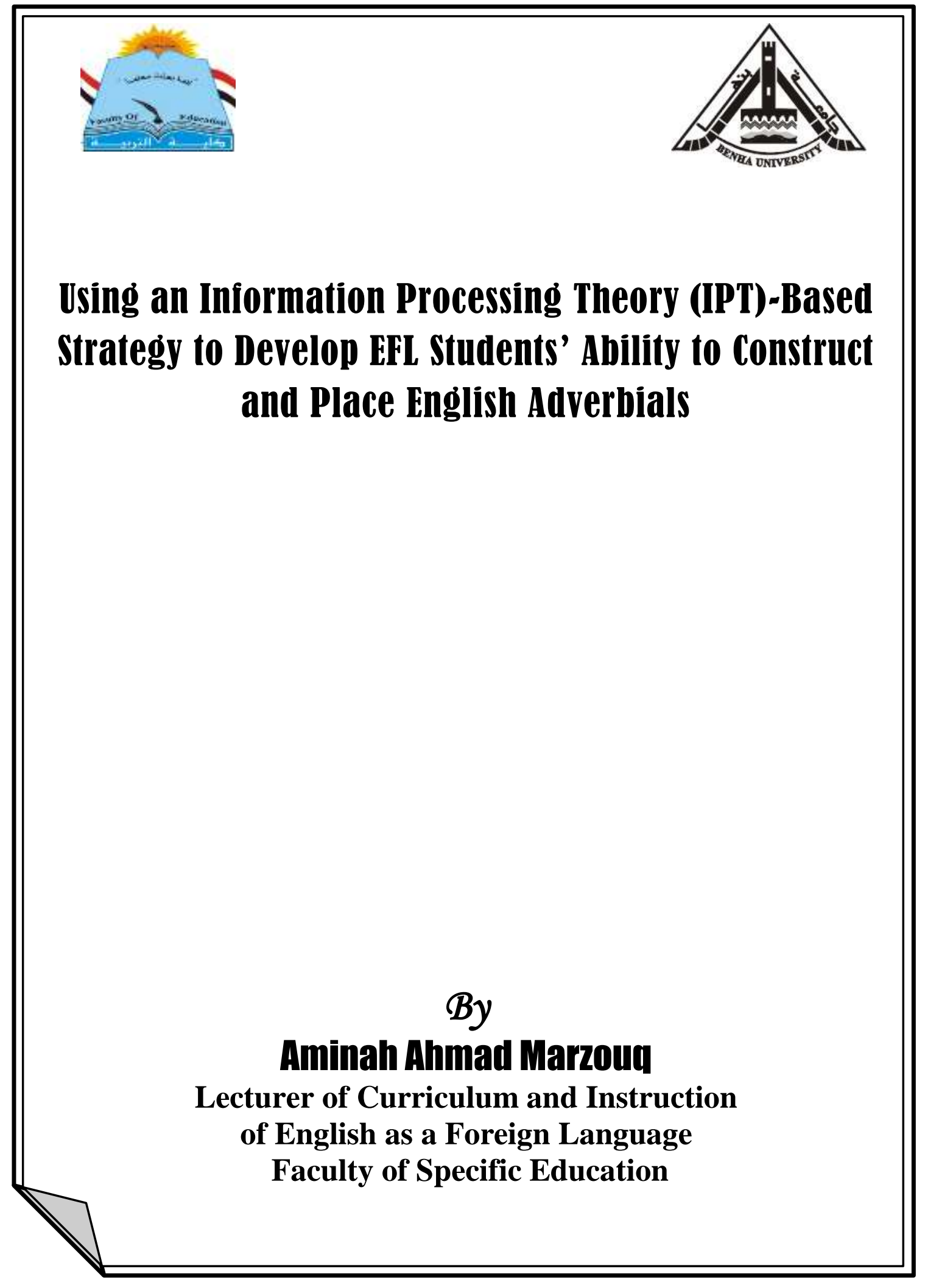




\title{
Using an Iniormation Processing Theory (IPT)-Based Strategy to Develop EFL Students' Ability to Construct and Place English Adverbials
}

\author{
By \\ Aminah Ahmad Marzouq \\ Lecturer of Curriculum and Instruction of \\ English as a Foreign Language \\ Faculty of Specific Education
}

\section{ABSTRACT}

The purpose of the present study was to develop EFL major students' ability of constructing and placing English adverbials through using a suggested information processing theory (IPT)-based strategy. The participants were sixty second year EFL students in the Section of English in the Faculty of Specific Education, Zagazig University. They were divided randomly and equally into two groups: an IPT-treatment group taught through the IPT-based strategy and a control group taught through the regular/traditional tutorials. The instruments used in this study were two tests: an adverbials construction test and an adverbials placement test. These tests were pre- and post-administered to the study groups. Statistically, t-test and Black's formula were conducted to analyze the data obtained from the preand post-administrations of the study tests. The results showed that there were statistically significant differences in the favor of the IPT-treatment group students in the post assessments of both tests. Additionally, IPT-treatment group significantly surpassed the control group in both tests. Ultimately, IPTbased strategy proved to be effective in developing EFL students' ability of constructing and placing English adverbials

Keywords: Information Processing Theory (IPT) - English Adverbials Adverbials Construction - Adverbials Placement 
استخداه استراتبية قائمة على نظرية تجهيز ومعالجة المعلومات لتنمية قدرة طلاب شعبة اللانة الإنجليزية علي بناء وتسكين عبارات الحال في اللغة الإنجليـزيلة

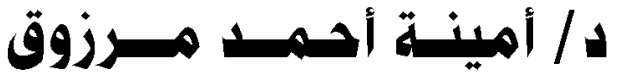

ملدرس مناهج وطرق تدريس اللفة الإنجليزية

بقسم العلوم التزبوية والنفسية

بكلية التربية النوعية - جامعة الزقازيـق

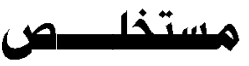

هـدفت الدراسـة الحالية إلى تتمية القدرة النحويـة على بنـاء وتسكين عبارات الحال باللغـة الإنجليزيـة لدى طلاب الفرقة الثانية بثعبة اللغـة الإنجليزيـة بكلية التربية النوعية ، وذلك باستخدام استراتيجية مقترحة قائمة على نظرية تجهيز ومعالجة المعلومات. وطُبقت الدراسة على عينة قِوامها ستون طالبة ، مقسمين عشوائياً إلى مجموعتين متساويتين ، مجموعة تجريبية ومجموعة ضابطة . واستخدمت الدراسة أدوات تمثلت في اختبارين موضوعيين ، أحدهما لقياس قدرة الطلاب على بناء عبارات الحال باللغة الإنجليزية ، والاختبار الثاني لقياس قدرة الطلاب على تسكين هذه العبارات في الجملة بشكل صحيح. وأجرت الدراسة اختبار (ت) للمقارنة بين متوسطات المجموعتين المشاركتين في الدراسة ، كما أُجريت معادلة 'بلاكك، للتحقق من فاعلية الاستراتيجية المقترحة. وأسفرت نتائج الدراسة عن فروق دالة إحصائياً بين متوسطات درجات التطبيق القبلي والبعدي لاختبارات الدراسة للمجموعة التجريبية لصالح التطبيق البعدي، كما وجلت فروق دالة إحصائياً بين متوسطات درجات طـلاب المجموعـة التجريبية والمجموعـة الضـابطة في التطبيق البعدي لاختبارات الدراسـة لصـالح المجموعـة التجريبيـة. وأثثتـت نتائج الدراسـة أن الاستراتيجية المقترحسة القائمسة على نظريـة تجهيز ومعالجة المعلومات فعّالة في تتمية قدرة طلاب اللغة الإنجليزيـة على بناء وتسكين عبارات الحال باللغة الإنجليزية. الكلمات المفتاحية: نظرية تجهيز ومعالجة المعلومات (IPT) - عبارات الحال باللغة الإنجليزية بناء عبارات الحال باللغة الإنجليزية - تسكين عبارات الحال باللغة الإنجليزية. 


\section{Introduction}

Teaching grammar always lies at the heart of teaching English as a foreign language. Teaching grammar rules train learners to put together appropriate lexical units (word classes: parts of speech) and syntactic constituents (grammatical classes: phrases and clauses) properly to construct grammatical meaningful sentences. These sentences can be analyzed in terms of word order to be categorized into arrangements of correct syntactic units (phrases, clauses or sentences of the language (Folse, 2012; Tallerman, 2011). Syntactic structures (patterns or constructions) are analyzable into sequences of "syntactic categories or syntactic classes which are analyzed by its turn as sets of syntactic features. These categories/classes are established on the basis of the syntactic relationships which the linguistic items have with other items in a construction" (Crystal, 2003, p. 471).

The idea that syntactic structures can carry meanings that are independent of the meanings of specific words has received a great interest among linguists and psycholinguists. Accordingly, a blossoming interest in the semantics of syntactic structures within the sentence begins to occupy a great corpus of research. This interest has taken two related forms: among linguists, as an intensified examination of the role that syntactic structures play in the learners' composition of sentencelevel meaning; and among psycholinguists, as a proposal for how learners might overcome some of the serious problems associated with word learning (Kako \& Wagner, 2001).

\section{Literature Review}

Learning a foreign language generally implies making mistakes in various areas, especially in grammar. Very common mistakes which learners make when producing grammatical structures involve the misuse of adverbials. EFL learners frequently mis-construct adverbials in in a form of derived single words, in a form of phrases or in a form of complete clause. This should not be surprising because adverbs are more difficult to be recognized than nouns, verbs, and adjectives. Adverbs express a various series of meanings and their grammar is quite complex (Sawalmeh, 2013). 
Concerning meaning, English adverbials express a large number of ideas such as manner, time, place (location or destination), contrast, concession, etc. Most adverbs of manner have a recognizable form; that is, they end in $-1 y$. Some other adverbs cannot be easily recognized by their form because they do not have a specific suffix. Besides, "they may modify almost any kind of construction in English: verbs, adjectives, other adverbs, and even whole sentences" (Hernández, 2006, p. 272; Tallerman, 2011).

Every word is a construction, every grammatical rule or template is a construction, and so forth. A crucial feature of constructions is that they are holistic: they express several linguistic features simultaneously. Furthermore, the construction or form of the adverbial is also significant, so a single word (lexical adverbs) will not be as heavy as an adverbial phrase (prepositional phrases or noun prases), nor as heavy as a larger unit such as an entire clause. With this mind, the reader can begin to see that an entire subordinate clause will function differently in the middle of the sentence from how it behaves at the end or beginning of a sentence. Thus, adverbials positioning can add emphasis or even deemphasize another word or clause in a sentence (Gholami \& Tahriri, 2017; Kuningas \& Leino, 2006).

\section{Construction of Adverbials}

In constructivism grammar, adverbials can be formulated in various structures. An adverbial may be a single word such as all lexical adverbs (the adverb word class); words which are lexically classified as adverbs (such as soon, now, late, quickly, kindly, paternally, etc.). Beyond the word level, another structure of the adverbial is a form of a phrase (either prepositional or nominal) (such as three times, to some extent, at the end, in a friendly way, with confidence, on the table, etc.). As construction intricacy gradually grows, the adverbial structures take the form of whole clauses. These clauses are dependent components of complex and compound complex sentences. They are introduced by certain subordinate conjunctions which link the clauses with each other and decide the relationship among them as well. For example, 'After the project has been opened, the president rewarded the distinguished workers' (Murphy, 2015; Tallerman, 2011). 


\section{Placement of Adverbials}

Word order phenomena are defined as a part of a particular kind of constructions; these constructions could be labeled ordering construction. In ordering constructions, the particular order of the parts of that construction is integrated with a certain sense; some other features of the construction often complete this sense (Gholami \& Tahriri, 2017). Unlike other elements of the sentences, adverbials are the most variable and movable ones. English language learners use adverbials in English in considerable numbers and functions without comprehending the deeper level of semantic implications or meaningfulness. Adverbials are the most variable units in the English language to be used anywhere- rule bound or rule free. However, adverbials cannot occur as pre-nominal attributive modifiers of nouns (Folse, 2012; Gholami \& Tahriri, 2017).

Furthermore, adverbials placement is very intriguing because "adverbial syntax seems to lead to quite puzzling questions concerning the interplay between issues of placement and issues of movement" (Delfitto, 2006, p. 103). Without question, adverbials placement calls for particular cases of accuracy for clarity to eliminate ill-formed sentences, but an EFL instructor should note the significance of teaching adverbial placement to students not only for sentence clarity but also to improve grammatical awareness and rhetorical emphasis in composition (Rutledge \& Fitton, 2015).

\section{Classification of Adverbials}

Classifying English adverbials is mainly based on either semantic or syntactic criteria or both. The case is that learners first learn the general distinction of various types of adverbials and then acquire the syntactic positions of adverbials of each type. What upper-mediate and advanced learners acquire about adverbials is the distinction of different adverbials and the different scopes they take in. There are two aspects about adverbials that learners have to acquire: (1) the general positions of adverbials within sentences; and (2) the varied scope of adverbials which is also closely related to syntax (Murphy, 2015; Zi-hong, 2010). 


\section{Adverbials of Frequency}

Adverbials of frequency tell how many times an action occurs, occurred, or will occur; they answer the question How often? Some of them are: always, often, usually, occasionally, annually, seldom, rarely, never, etc. Such adverbials are most often put in a particular place between the subject and the main verb, but they are place after the verb Be. For the rest of other cases, particularly formed as phrases, they are placed at the end of the clause such as again, too, also or phrases as for another time, once a week, per a minute, for an additional chance, for the second time, etc. (Folse, 2012; Murphy, 2015).

\section{Adverbials of Manner}

These adverbials tell in which manner an action occurs, how the action is done or will happen; they answer the question How? Some of them are: hard, fast, late, quickly, happily, angrily, suddenly, etc. In such cases, they most often come in final position, but adverbials ending in -ly can often go in mid-position if the adverb is not the main focus of the message (Swan, 2006). These adverbials may be structured as phrases like: with confidence, with difficulty, in a friendly way, with some hesitancy, etc. In case of being prepositional phrases, adverbials of manner should not be positioned in the middle since the sentence looks awkward. Furthermore, they should come first followed by adverbials of place and time, respectively (Folse, 2015; Richards \& Schmidt; 2010).

\section{Adverbials of Place}

These adverbials tell in which place an action happens, happened or will happen; they answer the question Where? Some of them are: here, there, near, faraway, ahead, outside, somewhere, etc. They may be formed as phrases like: in the street, on the top, within the building, on the beach, at some place, etc. These adverbials are placed at the end position after the verb and its complements, and before time adverbials. If they take the form of clauses, they are introduced by the subordinating connections either where or wherever; and then, they are placed after the main clause (Folse, 2012; Rutledge \& Fitton, 2015). 


\section{Adverbials of Time}

These adverbials tell about the time of an action; they answer the question When? They include: now, then, soon, tomorrow, yesterday, today, tonight, again, early, still, recently. Some of time phrases are: after three hours, before the end, in the next week, on Thursday, at ten o'clock, etc. They may be structured as clause of time beginning with one of time subordination conjunctions: after, before, when, till/until as soon as, while, since, once and as. They usually come at the end of the sentence. They do not usually come in the middle. However, they can be placed at the beginning to express emphasis. Additionally, the adverb 'sometimes' can occur in all three positions: front, mid and end positions (Rutledge \& Fitton, 2015; Zhang \& Koller, 2015).

\section{Adverbials of Purpose}

These adverbials tell for the purpose for which someone does something. They answer the question For whom/or What purpose? They are formed in either phrases or clauses. Examples of phrases are: for themselves, for everyone, for you, for fear of arrest, to avoid suspicion, so as to manage, in order to arrange, etc; they are placed at the end of the clause. Purpose clauses begin with the conjunctions: so that or in order that in the affirmative states clauses and with lest or for fear that in negative clauses. They always follow the main clause, i.e. they are placed at the end of the sentence (Murphy, 2015; Richards \& Schmidt; 2010).

\section{Adverbials of Concession}

Adverbials of concession are alternatively called adverbials of contrast; they are used to show that the result of an action (or of a state) is unexpected. Concerning their construction, in form of phrases, they are formed in prepositional phrases beginning with either despite, in spite of, notwithstanding or for all. In a form of clauses, adverbials of contrast are structured in dependent clauses beginning with any of the following subordinating conjunctions: although, though, even though, much as, (adj.) as, (adj.) though, and however + (adj) or (adv.). Concerning their placement, in most cases they follow the main clause; nevertheless, they can precede it especially for the sake of emphasis (Hewings, 2005; Murphy, 2015; Rutledge \& Fitton 2015). 


\section{Conjunctive Adverbials (Adjuncts)}

Conjunctive adverbials as a term is used alternatively with linking adverbials, sentence connector, linking adjuncts or conjunctive adjuncts. There are six different semantic categories of linking adverbials: enumeration (such as first, second, next, etc.); addition (such as moreover, furthermore, besides, etc.); summation (such as briefly, in conclusion, to sum up, to summarize, in brief, etc.); apposition (such as that's to say, again, namely, etc.); result/inference (as hence, thus, consequently, accordingly, etc.); contrast/concession (such as paradoxically, on the other hand, in contradiction, on the contrary, etc.; and transition (such as afterwards, next, finally, eventually, etc.) (Carter \& McCarthy, 2006; Yong-Yae, 2013).

Accordingly, linking adjuncts accomplish connective functions, connecting units of discourse of differing sizes including sentences or units larger than a sentence (e.g., a paragraph). They play a critical role in establishing explicit cohesion in text; thus, they are recognized as important writing tools for EFL learners in academic writing. For more explanation, linking adjuncts explicitly indicate the semantic relationship between two different syntactic structures; i.e. two clauses or sentences or paragraphs. They can be further classified into several types: additive, resultative, contrastive, inference, summative, concessive, listing, narrative and meta-textual. From another perspective, adjuncts can be divided into four main categories: additive, adversative, causal/resultative and sequential (Lei, 2012; Kian \& Gorjian, 2018).

\section{Related Studies}

Recent empirical studies have assured difficulties and problems concerning using English adverbials. Hernández (2006), for example, found that the leaners over-generalized the rules for placing frequency adverbs; they frequently mis-placed adverbs between the main verb and its direct object; it was their most common error. Hence, she assured that adverbs position in English is very problematic, and it can confuse both students and instructors. An error analysis study by Al Fadda (2012) concluded that EFL students encounter many grammatical difficulties in positioning adverbs within a sentence and how to combine sentences to 
write a paragraph correctly through connective adverbials. From the same perspective, Farooq (2012) analytically confirmed difficulties of placement of modifiers, placement of adverbs and other grammatical problems which EFL learners face in writing tasks. Also, Lei (2012) assured the EFL learners' misuse, either overusing or under using, of English adverbials. Semantically and stylistically misuse of adverbials is clearly concluded by Garner (2013) who went a step forward to achieve significant improvements among the EFL learners via data-driven learning. Again, the notion of overuse, underuse and/or misuse of English adverbials was the focus of studies by Leedham and Cai (2013), Yong-Yae ( 2013) and Liu (2014).

Form and function of English adverbials were definitely investigated by Dedham's study (2015) which attributed this poor performance partially to the use of the rules of the native language and the use of literal translation by the students; i.e. intra-lingual transfer. Consequently, some studies like that by Rutledge and Fitton (2015) highlighted the importance of teaching EFL learners adverbial placement explicitly to increase rhetorical awareness achieving some significant improvements among EFL learners composition. Adverbials formation again was the focus of a study by Ngangbam (2016) who recommended the need for direct teaching for English adverbials. Furtermore, Güneş (2017), whose study recorded a significant overuse of linking adverbials even among EFL doctoral students, gave more practical recommendations such as extensive awareness-rising activities and including authentic examples in the ELT materials on adverbials.

It becomes cut-clear that even post-graduate students also have encountered difficulties in using English adverbials as investigated by Sheikhani and Abdollahi-Guilani (2017) who confirmed the notion of adverbials misplace, overuse, or underuse. On the part of relatively high proficiency level of EFL learners, Yilmaz and Dikilitas (2017) found significant misuse of adverbials form and function in learners' academic writing. They advanced a step forward to imply that there is a need for systematic explicit instruction of EFL adverbials and for raising learners' awareness in the meanings and functions of adverbials in EFL writing. 
English adverbials difficulties occurring in academic writing were again the focus of a qualitative study by Atashian and Al-Bahri (2018). They investigated the strategies and solutions to tackle this problem. Their findings clearly proved that three grammatical points, namely, tenses, adverbs and pronouns were the students' most frequent mistakes.

Considering all the previous studies, the appropriate and correct use of English adverbials remains problematic for even advanced learners of English even though EFL learners are taught adverbials even at an early stage of language learning. The most common problems are mis-forming adverbials, overusing certain ones, underusing others, and misplacing most of them.

Language teachers are constantly searching for the most recent and effective methods of teaching. Teaching language to non-native speakers of English involves certain problems and challenges at all levels of instruction. The need to create an effective learning environment has led educators to explore different dimensions of teaching, learning and assessment styles (Vaezi, 2012).

Consequently, the present study attempted to help overcome such difficulties and deficiencies in the construction and placement of English adverbials through suggesting and using a new strategy in English language teaching and learning; namely, an information processing theory (IPT)-based strategy.

\section{Information Processing Theory (IPT)}

Cognitive learning theorists emphasize that learning implies formation of mental structures and processing of information; to cognitivists, learning is an internal mental phenomenon inferred from what learners say and do. Consequently, learning best takes place by doing or proceeding it (Chunk, 2012). From a cognitive point of view, learning language is not merely a matter of habit formation as the Behaviourists believed, but, like any other kind of learning, it involves taking in information which is then processed and acted upon. Learning a language is a progression from limited and controlled processing of information requiring much cognitive effort to automatic processing with little effort in handling a lot of information simultaneously (Dornyei, 2009; Miller, 2016). 
The information processing theory (IPT) is a cognitive approach to understanding how the human mind handles and transforms sensory information. The theory assumes that information which comes from the environment (sensed) is subject to mental processes beyond a simple stimulus-response pattern. "Input" coming from the environment goes through the cognitive systems which is later measured by the "output". Information which is received can take several paths depending on attention, encoding, recognition, and storage. Although more primitive sensory areas of the brain first accept environmental input, the central executive procedure controls how much information is being processed. Besides, through the process of maturation, a learner develops greater abilities to attend to stimulus, recognize patterns, encode, and retrieve information automatically (Miller, 2016; Zhou \& Brown, 2017).

The IPT has three basic components which are: sensory memory (SM), short term memory (STM) or working memory, and long term memory (LTM).

\section{Sensory Memory}

Sensory Memory (SM) is where information received and gathered from the environment is stored. It is also called sensory register (sensory motor). Sensory memory is very limited, passive, and lasts about 5-3 seconds. It has the capacity of holding about 4 items (pieces of information). It is affected by attention. In order for information to enter the short-term memory from the sensory register, it must be attended to by the learners' senses. Information which is not attended to is lost from the sensory memory and never enters the short-term memory (Lutz \& Huitt, 2003; McLeod, 2008).

\section{Short-Term Memory}

Short-Term Memory (STM) is also known as working memory. STM is where information meets what is already known, and where thinking is done. A learner perceives and attends to sensual stimuli/information; that information is then actively processed based on information stored in LTM. Applying strategies such as rehearsal (repeating information verbally) and chunking (categorizing information together in one memory slot) can expand the capacity of short-term memory (Baddeley, 2001; Lutz \& Huitt, 2003). 
At the STM stage, interference during perception is the principal cause of forgetting information. STM can hold approximately seven items instantly. The key procedure here is repetition; this repetition is termed rehearsal. Rehearsal can also be used to get information into the following memory, i.e. LTM, but it is very inefficient and immediate. Rehearsal mainly serves a maintenance function; it can be used to keep information in STM. If a learner is interrupted during rehearsing an item of information, he/she responds and interferes with rehearsal, and the information is lost. Accordingly, he/she must call the information again (Baddeley, 2001; Zhou \& Brown, 2017).

A model of working memory consists of three components. The executive controls system oversees all working memory activities, including selection of information, method of processing, meaning, and finally deciding whether to transfer it to long term memory or to forget it. Two counterparts of this system are the auditory loop, where auditory information is processed, and the visual-spatial check-pad, where visual information is processed. Sensory memories which are transferred into working memory will last for 15-20 seconds, with a capacity for 5-9 items or chunks of information. Information is maintained in working memory via maintenance or elaborative rehearsal. Maintenance refers to repetition, while elaboration refers to the organization of information (such as chunking or chronology) (Baddeley, 2001; Lutz \& Huitt, 2003).

The processing which occurs in working memory is influenced by a number of factors. Firstly, individual learners have varying levels of cognitive load, i.e. the amount of mental effort they can engage in at a given moment, due to individual characteristics and intellectual capacities. Secondly, information which has been repeated many times becomes automatic and thus does not require much cognitive resources (e.g. writing different words). Lastly, according to the task at hand, individual learners use selective processing to focus attention on information that is highly relevant and necessary (Bigus, 2011; David, 2015). 


\section{Long-Term Memory}

Long term memory is the final stage of the information processing model. In LTM capacity and duration are considered unlimited, and the principal cause of forgetting is failure to attend to or retrieve the information LTM includes various types of information: declarative (semantic and episodic), procedural (how to do something), and imagery (mental images). Differing from the previous memory constructs, LTM has unlimited space. The crucial factor of long term memory is how the information is well organized. This is affected by appropriate encoding (elaboration processes in transferring information to long term memory) and retrieval processes (scanning memory for the information and transferring into working memory so that it is ready to be used). The degree of similarity between the way information has been encoded and the way it is being accessed will shape the quality of retrieval processes. Generally, people/learners remember a lot or less information than it is actually stored there (Bigus, 2011; David, 2015).

From another perspective, in LTM, there are five types of knowledge: declarative, procedural, episodic, imagery, and strategic knowledge; there also exists one collective type called conceptual knowledge. For the LTM stage, the representation of processed information is semantic (based on meaning); and processing becomes gradually automatic. By using the correct methods, information can be transferred from the short-term memory into the long-term memory where it can be transformed, retained in schemas, restructured if necessary, and kept for long periods of time. Information which is stored in the long-term memory does not need to be rehearsed. In order to retrieve information from the long-term memory, short-term memory must be used. Usually if a learner "forgets" something that is stored in the long-term memory, he/she as simply forgotten how to retrieve it or where it is stored (David, 2015; Zhou \& Brown, 2017). 
Miller (2016, pp. 283-287) answers the question how information processing theory is practically applied in teaching. He assumes that IP combines elements of both quantitative and qualitative development. Qualitative development occurs through the emergence of new strategies for information storage and retrieval, developing representational abilities (such as the utilization of language to represent or form new concepts), or attaining problem-solving rules. According to Miller, the qualitative and quantitative components often interact and interrelate together to develop new and more efficient strategies within the processing system. Increased knowledge enables the learners to more readily access information from their long-term storage and utilize it in appropriate situations. The more associations a learner is able to make and the more complex his/her network of associations, the better his/her information recall.

To put it definitely applicable, applying information processing theory in EFL learning and teaching implies that the language is a hierarchical set of skills where learning higher level components depend on acquisition of lower level ones. This makes language a complex skill which must be practiced to attain higher levels. Furthermore, learning is dynamic, so knowledge which is learned can be changed, altered or even transformed when learners acquire new information. This is called restructuring which helps for faster and more coordinated response time during a learning task. This allows the learner to develop language learning and attain higher levels.

In the light of the aforementioned discussion, the researcher designed a suggested strategy based on information processing theory. The strategy is presented and illustrated in detail below. 
Table (A) IPT-Based Strategy

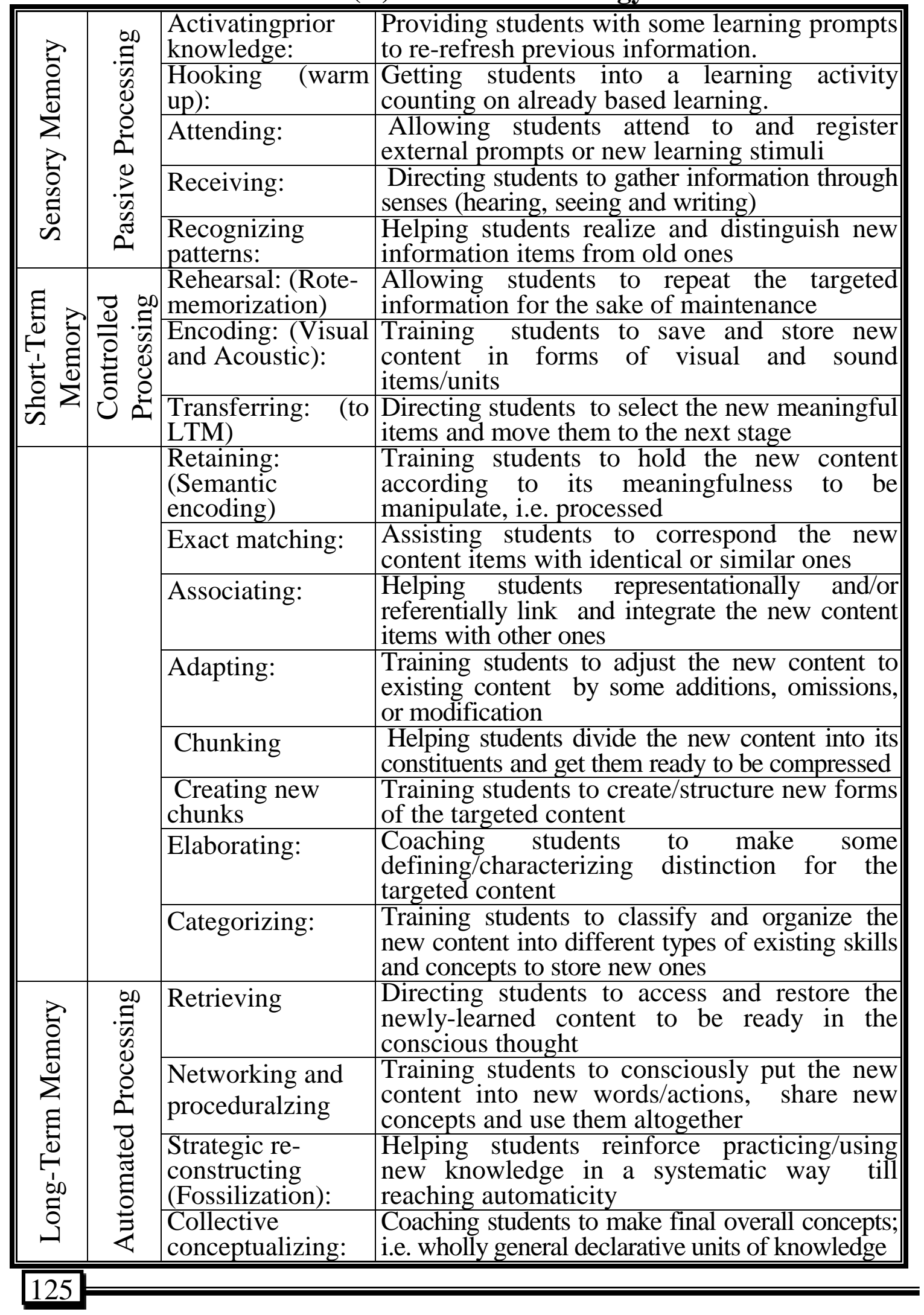


Unnegotiablly, teaching adverbials construction and placement to EFL learners is greatly significant for improving their grammatical knowledge. Learning adverbials has been already hard enough for EFL learners, but EFL teachers should still expand a clear-cut understanding of adverbials positioning for emphasis when they teach adverbials placement. Adverbials position may not only modify the meaning of the sentence but also make the sentence grammatical or ungrammatical. In addition, complex adverbial structures make their writing grammatically weighty and eloquent. Accordingly, as they develop academically, students' lack of adverbials use in written articles can show a weakness or misunderstanding of grammatical and rhetorical awareness for EFL learners (Gnanaseelan, 2016; Zhang \& Koller, 2015).

Generally speaking, EFL intermediate and upper-intermediate learners, among them Arab learners, are frequently reported in various studies that they can neither construct nor place the constituents and parts of English sentences in the correct patterns. Complexity particularly multiplies in the case of adverbials which have different possible forms and positions (Hernández , 2006; Al Fadda, 2012; Garner, 2013; Liu, 2014; Yilmaz and Dikilitas, 2017; Atashian \& Al-Bahri, 2018).

To make sure that there is an actual problem, the researcher piloted a mini-test for $50 \mathrm{EFL}$ major students instructing them to write a composition about 200-250 words paying their attention to use as many adverbials as they can. Error analysis as a descriptive method was performed to detect the most frequently mistaken adverbials in terms of their construction and placement. The researcher counted the percentage by dividing the number of mistakes by the total number of usage for each student. Then, the Mean was counted. The findings showed the percentages of adverbial mistakes as follows: frequency $82 \%$, manner $81 \%$, place $78 \%$, time $78 \%$, purpose $76 \%$, concession $75 \%$, connective $73 \%$ respectively.

\section{Statement of the Problem}

In the light of the aforementioned argumentation alongside with the findings of the pilot study, the problem of the present study can be phrased in the following statement: 'The EFL major students showed 
deficiencies/weaknesses in constructing and placing English adverbials'. Accordingly, the problem of the study can be stated in the following main question: "What is the effectiveness of an information processing theory-based strategy in developing EFL major students' ability to construct and place English adverbials?"

\section{This main question can be sub-divided into the following questions:}

- What is the actual performance of the EFL major students in constructing and placing English adverbials?

- To what extent can an information processing theory (IPT)-based strategy develop EFL major students' ability of constructing targeted adverbials?

- To what extent can an IPT-based strategy develop EFL major students' ability of placing the targeted adverbials?

\section{Purpose of the Study}

\section{The present study attempted to achieve the following aims:}

- Developing the grammatical aspects targeted in this study which are: the construction and placement of English adverbials for EFL major students in the Section of English in the Faculty of Specific Education.

- Investigating the effectiveness of an IPT-based strategy in developing EFL major students' ability to construct and place some English adverbials.

\section{Hypotheses of the Study}

\section{The study attempted to verify the following hypotheses:}

- There would be statistically significant differences between the means of the IPT-treatment group students in their performance on the prepost assessments of Adverbials tests favoring the post-assessment.

- There would be statistically significant differences between the means of the IPT-treatment group students and the control group students in their performance on the post-assessment of the English Adverbials tests wholly favoring the IPT-treatment group.

- The IPT-based strategy would be effective in developing EFL major students' Adverbials Ability wholly and dimensionally (Construction and Placement). 


\section{Significance of the Study}

The present study may be:

- Useful to the field of EFL teaching and learning in making use of new strategies derived from recent learning theories as information processing theory.

- Significant for English grammar course designers for EFL learners throughout planning and designing such courses.

- Beneficial for the EFL major students in the Faculty of Specific Education to know how to grammatically use adverbials and successfully perform in their classrooms using new strategies and techniques.

\section{Instruments of the study}

Two objective tests: an adverbials construction test and an adverbials placement test (prepared by the researcher).

\section{Delimitations of the Study}

\section{This study was delimited to:}

- Sixty second year students in the Section of English in the Faculty of Specific Education, Zagazig University.

- Some of the English adverbials targeted in the present study, viz. adverbials of frequency, manner, place, time, purpose, concession and connective.

\section{Definition of Terms}

In the light of the aforementioned theoretical background, the procedural definitions of the present study variables can be coined as follows:

\section{IPT-based strategy}

It is a suggested strategy which consists of a series of deliberate, successive and co-interrelated, but seemingly separate, strategic procedures in which EFL students engage in order to achieve the utmost 
learning output. The strategy is divided into three broad divisions; each of them corresponds to a stage memory and represented in a form of suitable processing; namely, sensory memory corresponds to passive processing, STM corresponds to controlled processing, and finally LTM corresponds to both deep processing and automated processing.

\section{English Adverbials Construction}

It is the EFL major students' grammatical ability to correctly compose and structure English adverbials in forms of phrases and clauses according to certain grammatical patterns.

\section{English Adverbials Placement}

It is the EFL major students' syntactic ability to correctly position English adverbials in the correct syntactic word order paying attention to their syntactic features and semantic characteristics within sentences.

\section{Methodology and Data Collection}

Participants: The participants of the study were sixty second year EFL learners whose major is English in the Faculty of Specific Education in the academic year 2018/2019. The study was conducted during the second term. They were randomly selected and equally divided into two groups: a treatment group $(n=30)$ and a control group $(n=30)$. The treatment group students were taught through the suggested IPT-based strategy, while the control group students were taught through regular teaching. Homogeneity/Equivalence among the participants had to be punctuated. Their age ranged from 19 to 20 years old and they had the same environmental and educational circumstances, i.e. all of them used to study in the governmental schools and none had an English or American parent. Furthermore, all of them are females and they were taught by the same teacher (the researcher). Finally, their level in constructing and placing English adverbials were measured by the study tests. 
Table (1) Homogeneity of the Study Groups on the Preadministration of Adverbials Tests

\begin{tabular}{|c|c|c|c|c|c|c|}
\hline Adverbials & Groups & $\mathbf{N}$ & Mean & $\begin{array}{c}\text { St } \\
\text { Deviation } \\
\end{array}$ & $\begin{array}{c}\text { T. } \\
\text { Value } \\
\end{array}$ & Sig. \\
\hline \multirow{2}{*}{$\begin{array}{c}\text { Adverbials } \\
\text { Construction }\end{array}$} & $\begin{array}{l}\text { Treatment } \\
\text { Group }\end{array}$ & 30 & 26.65 & 2.00624 & \multirow{2}{*}{2.224} & \multirow{2}{*}{$\begin{array}{l}\text { Non } \\
\text { sig. }\end{array}$} \\
\hline & Control Group & 30 & 26.35 & 1.86771 & & \\
\hline $\begin{array}{l}\text { Adverbials } \\
\text { Placement }\end{array}$ & $\begin{array}{c}\text { Treatment } \\
\text { Group }\end{array}$ & 30 & 27.43 & 2.08676 & 2.207 & $\begin{array}{l}\text { Non } \\
\text { sig. }\end{array}$ \\
\hline \multirow[t]{2}{*}{ Total } & $\begin{array}{c}\text { Treatment } \\
\text { Group }\end{array}$ & 30 & 54.08 & 3.52270 & \multirow[t]{2}{*}{2.118} & \multirow{2}{*}{$\begin{array}{l}\text { Non } \\
\text { sig. }\end{array}$} \\
\hline & Control Group & 30 & 53.89 & 2.81823 & & \\
\hline
\end{tabular}

Table (1) shows that the obtained "t-values" for all adverbials, i.e. wholly and dimensionally, were NOT statistically significant at the 0.05 level. Therefore, it could be concluded that there was homogeneity among the students of the treatment group and those of the control group on the pre-administration of the English adverbials tests.

\section{Instruments:}

The instruments of the study comprise two tests: an Adverbials Construction Test and an Adverbials Placement Test.

1- Adverbials Construction Test was intended to assess the EFL major students' ability to construct English adverbials. The test as a whole is an objective test consisting of two sections: Section One and Section Two. Section One consists of thirty-five sentences which stimulate right $(\sqrt{ })$ or wrong $(X)$ responses; and Section Two consists of thirtyfive sentences which stimulate short completion responses as shown in front of each sentence. In each section five sentences/items are dedicated to measure the construction of one type of English adverbials targeted in this study (see Appendix 1).

2- Adverbials Placement Test was intended to assess the EFL major students' ability to place English adverbials. The test as a whole is an objective test consisting of two sections: Section One and Section Two. Section One consists of thirty-five sentences which stimulate right $(\sqrt{ })$ or wrong $(\mathrm{X})$ responses; and Section Two consists of thirtyfive sentences which stimulate short completion responses as shown 
in front of each sentence. In each section five sentences/items are dedicated to measure the placement of one type of English adverbials targeted in this study (see Appendix 2).

- Validity: (Face-Content): A major concern of a test is content validity which is the degree to which the items of that test are representative of the content and objectives intended to be assessed. Since language tests measure overall abilities in different language domains, the adverbials construction and placement tests of the present study were related to both the objectives and the content taught. Thus, content validity of the tests was assured on the basis of a logical correspondence between the tests items and the objectives and content being covered as recommended by Wiersma and Jurs (1985).

- Face Validity: A checklist of the adverbials targeted in the present study intended to be measured attached to the items of the two tests were submitted to the jury members for further suggestions, modifications and comments concerning the clarity, appropriateness and sufficiency of the test items. In the light of the jury members' opinions, the researcher prepared the tests for the final administration.

- Reliability of the Tests: The tests were administered to a group of 30 students in the Section of English, in the Faculty of Specific Education, in Februray 2019. Ten days later the test was readministered to the same sample; then, the reliability of each test was calculated.

Table (2): Adverbials Construction and Placement Tests Reliability

\begin{tabular}{||c|c|c|c|c||}
\hline \multirow{2}{*}{ Variable } & \multicolumn{3}{|c|}{ Reliability Co-efficient } & \multirow{2}{*}{ Significance } \\
\cline { 2 - 4 } & Paerson & Kendal & Spearman & \\
\hline \hline Construction Test & 0.879 & 0.856 & 0.849 & 0.1 \\
\hline Placement Test & 0.858 & 0.861 & 0.837 & 0.1 \\
\hline
\end{tabular}

As shown in Table (2), the co-efficient values were significant at 0.01 . It could be said that the tests were reliable. 
- Timing the Tests: The testing time of each test was estimated by computing the mean time spent by the fastest student and the slowest student in answering the whole test.

Table (3) Timing the Adverbials Construction and Placement Tests

\begin{tabular}{||l|c|c|c||}
\hline \multicolumn{1}{|c|}{ The variable } & $\begin{array}{c}\text { The fastest } \\
\text { student }\end{array}$ & $\begin{array}{c}\text { The slowest } \\
\text { student }\end{array}$ & The mean \\
\hline \hline Construction Test & 54 (minutes) & 69.5 (minutes) & 61.75 (minutes) \\
\hline Placement Test & 51.5 (minutes) & 65.5 (minutes) & 58.5 (minutes) \\
\hline
\end{tabular}

As shown in Table (3), in the construction test the fastest student spent 54 (minutes) and the slowest student spent 69.5 (minutes). Thus, the mean of these two durations was 61.25 (minutes), i.e. approximately One Hour. Furthermore, in the placement test the fastest student spent 51.5 (minutes) and the slowest student spent 65.5 (minutes). Thus, the mean of these two durations was 58.5 (minutes), i.e. approximately One Hour.

Scoring the Tests: For each test, the total mark of the whole test is "70 marks" divided as follows: "35" marks for section one and " 35 " marks for section two; i.e. a mark for each item. Guided by model answers, scoring of the tests was conducted by the researcher and another instructor for the sake of more accuracy.

Study Material: The content of the proposed IP-based strategy is mainly a grammatical one. It consists of seven instructional sessions. The content of the sessions is a direct and explicit reflection of the adverbials types targeted in the study. That's to say, at least one adverbial type is presented and tackled in one session. Using the suggested IP-strategy, the researcher prepared the chapter discussing English adverbials in the grammar course designated to second year English major students. The researcher represented this chapter in light of the systematic steps and learning activities/tasks constituting the strategy. The students were provided with copies of the new content to be ready for experimentation. Besides, the students were provided with the content necessary for a warming up and training session and the revision session. 


\section{Study Design}

This was a quasi-experimental study having two groups, one of them was a treatment group and the other was a control group. The control group received regular teaching. The treatment group was taught according to the IPT-based strategy during eleven weeks approximately (seven instructional sessions, a warming up and training session and a final revision and summary session in addition to the time of the pre-and post-administrations of the study tests.

Study Procedures: The study took place over eleven weeks in addition to the time of the pilot tests. After randomly assigning the students into two groups, the researcher pre-administered the tests of the study for the two groups. Then, she held a warming up and training session for the treatment group. The aim of this session was to tell the participants the objectives and importance of the strategy to raise their motivation and get them activated for participation. During this session, the researcher also activated the students' previous knowledge concerning English adverbials and gave them overall view of IPT. Then, she trained them to apply the suggested IPT-based strategy to be ready for the actual experimentation. Afterwards, the treatment group students were taught through the IP-strategy for seven sessions, a session per a week; while the control group students were taught through the regular traditional method. Then each group received a final session dedicated for review and designed in the same method each group was taught. Finally, the researcher post-administered the tests of the study.

Table (A)The Scope and Sequence of the Study

\begin{tabular}{|l|l||}
\hline \multicolumn{2}{|c|}{ Administering the Pilot Test } \\
\hline \multicolumn{2}{|c||}{ Pre-administration of the Study Tests } \\
\hline \hline The First Session & Warm up and Training \\
\hline The Second Session & Frequency Adverbials \\
\hline The Third Session & Manner Adverbials \\
\hline The Fourth Session & Place Adverbials \\
\hline The Fifth Session & Time Adverbials \\
\hline The Sixth Session & Purpose Adverbials \\
\hline The Seventh Session & Concession Adverbials \\
\hline The Eighth Session & Connective Adverbials \\
\hline The Ninth Session & Overall revision and Summary \\
\hline Post-administration of the Study Tests \\
\hline \hline
\end{tabular}




\section{Data Collection}

To best achieve the aims of the present study, the researcher collected the data through administering two tests; the tests were preand post-administered to the study participants. The data collected were analyzed using the Statistical Package for Social Sciences (SPSS) programme, version 16 in addition to Black's formula for accounting the overall gain ratio.

\section{Verifying Study Hypotheses}

The first hypothesis stated: "There would be statistically significant differences between the means of the IPT-treatment group students in their performance on the pre-post assessments of Adverbials tests favoring the post-assessment". T-test for paired samples was used to verify this hypothesis.

Table (4)Results of (t-test) of the Pre- and Post-Mean Scores of the IPT-Treatment Group in Overall EFL Adverbials Ability and its Components

\begin{tabular}{|l|l|l|l|l|l|l|}
\hline Adverbials Tests & $\begin{array}{c}|c| \\
\text { IPT- } \\
\text { treatment } \\
\text { Group }\end{array}$ & $\mathbf{N}$ & Mean & $\begin{array}{c}\text { St } \\
\text { Deviation }\end{array}$ & $\begin{array}{c}\text { T. } \\
\text { Value }\end{array}$ & Sig. \\
\hline \hline Construction Test & Pre & 30 & 26.65 & 2.00624 & 1.14 & .01 \\
\cline { 2 - 6 } & Post & 30 & 63.93 & 2.50525 & & \\
\hline Placement Test & Pre & 30 & 27.43 & 2.08676 & 1.12 & .01 \\
\cline { 2 - 5 } & Post & 30 & 65.74 & 1.47609 & & \\
\hline Overall Ability & Pre & 30 & 54.08 & 3.52270 & 1.54 & .01 \\
\cline { 2 - 5 } & Post & 30 & 129.67 & 3.52316 & & \\
\hline
\end{tabular}

As illustrated in Table (4), the mean scores of the IPT-treatment group students in the post-assessment of the adverbials tests are higher than those in the pre-assessment, where t-value is (1.14) for Adverbials Construction, (1.12) for Adverbials Placement, and (1.54) for the overall ability. Each of these values is significant at the 0.01 level of significance. Thus, this hypothesis is accepted. These differences can be attributed to the suggested IPT-based strategy which the IPT-treatment group students have experienced. 
The second hypothesis stated: "There would be statistically significant differences between the means of the IPT-treatment group students and the control group students in their performance on the postassessment of the English Adverbials tests wholly favoring the IPTtreatment group". T-test for independent samples was used to verify this hypothesis.

Table (5)Results of (t-test) of the Post-Mean Scores of the IPTTreatment Group and the Control Group in the Overall EFL Adverbials Ability and its Components

\begin{tabular}{|c|l|l|l|l|l|l|}
\hline $\begin{array}{c}\text { Adverbials } \\
\text { Tests }\end{array}$ & \multicolumn{1}{|c|}{ Groups } & $\mathbf{N}$ & Mean & $\begin{array}{c}\text { St } \\
\text { Deviation }\end{array}$ & $\begin{array}{c}\text { T. } \\
\text { Value }\end{array}$ & Sig. \\
\hline \hline \multirow{2}{*}{ Construction Test } & IPT-treatment & 30 & 63.93 & 2.50525 & 63.15 & .01 \\
\cline { 2 - 6 } & Control & 30 & 26.41 & 1.57219 & & \\
\hline Placement Test & IPT-treatment & 30 & 65.74 & 1.47609 & 85.21 & .01 \\
\cline { 2 - 6 } & Control & 30 & 30.31 & 1.48302 & & \\
\hline OverallAbility & IPT-treatment & 30 & 129.67 & 3.52316 & 119.73 & .01 \\
\cline { 2 - 5 } & Control & 30 & 56.72 & 2.89528 & & \\
\hline
\end{tabular}

As illustrated in Table (5), the mean scores of the IPT-treatment group students in the post-assessment of the EFL Adverbials tests are higher than those of the control group, where t-value is (63.15) for the Construction Test, (85.21) for the Placement Test, and (119.73) for the overall ability. Each of these values is significant at the 0.01 level of significance. Therefore, this hypothesis is accepted. These differences can be attributed to the suggested IPT-based strategy which the IPtreatment group students have experienced.

The third hypothesis stated: "The IPT-based strategy would be effective in developing EFL major students' Adverbials Ability wholly and dimensionally (Construction and Placement)". Black's Formula was computed to verify this hypothesis. 
Table (6)Results of Gain Ratio of the IPT-Treatment Group in

Adverbials Ability according to Black's Formula

\begin{tabular}{|c|c|c|c|c|}
\hline Adverbials Tests & $\begin{array}{c}\text { IPT- } \\
\text { treatment } \\
\text { Group } \\
\end{array}$ & Mean & $\begin{array}{l}\text { Total } \\
\text { Score }\end{array}$ & $\begin{array}{l}\text { Gain } \\
\text { Ratio }\end{array}$ \\
\hline \multirow{2}{*}{ Construction Test } & Pre & 26.65 & \multirow{2}{*}{70} & \multirow{2}{*}{1.5} \\
\hline & Post & 63.93 & & \\
\hline \multirow{2}{*}{ Placement Test } & Pre & 27.43 & \multirow{2}{*}{70} & \multirow{2}{*}{1.6} \\
\hline & Post & 65.74 & & \\
\hline \multirow{2}{*}{ Overall Ability } & Pre & 54.08 & \multirow{2}{*}{140} & \multirow{2}{*}{1.5} \\
\hline & Post & 129.67 & & \\
\hline
\end{tabular}

As shown in Table (6), the overall gain ratio is (1.5), so the suggested IPT-based strategy is effective in developing EFL students' Adverbials Ability. In addition, the gain ratio values of EFL students' Adverbials Ability components are as follows: the Construction Ability is (1.5), and the Placement Ability is (1.6). These values are satisfactory ones. Thus, this hypothesis is accepted.

Discussion of the results: Statistical treatments and quantitative analysis showed that the IPT-treatment group students' post-performance is better than their pre- performance in the EFL Adverbial Ability wholly and dimensionally. The mean scores in the pre-assessment of the Construction Ability and Placement Ability were (26.65) and (27.43) respectively. These means increased to be (63.93) and (65.74) respectively in the post-assessment. The same can be said about the means of the overall scores. The overall mean of the Adverbials Ability was (54.08) in the pre-assessment and increased to become (129.67) in the post-assessment.

Comparing the results of the IP-treatment group students (taught through the suggested IPT-based strategy) and the control group students (taught through the regular method) revealed that the IPT-treatment group outperformed the control group in the post-assessment of the 
Adverbials Ability tests wholly and dimensionally. The IPT-treatment group students' mean of the overall EFL Adverbials Ability was (129.67) while that of the control group was (56.72). In addition, the IPT-treatment group students' means of EFL Adverbials Ability tests were: (63.93) for the Construction Ability and (65.74) for the Placement Ability; whereas, those of the control group were (26.41) for the Construction Ability and (30.31) for the Placement Ability.

The suggested IPT-based strategy proved to be effective in developing EFL students' adverbials ability. Black's Formula revealed that the gain ratio was (1.5) for overall EFL Adverbials Ability, (1.5) for Construction Ability and (1.6) for Placement Ability. These gain ratio values were considered satisfactory. Accordingly, the IPT-based strategy, then, was effective.

Interpretation of the Results: The results of the present study showed that the IPT-treatment group students (taught through the IPTbased strategy) outperformed better in the post-administration of the EFL Adverbials Ability tests wholly and dimensionally (in the Construction Ability and the Placement Ability). There were significant differences among the mean scores of the pre-administration compared to those of the post-administration favoring the post-administration. That's to say, they achieved significant developments in EFL Adverbials Ability wholly and dimensionally.

For more validation, the post-performance means of the IPTtreatment group were compared to those of the control group favoring the IPT-treatment group on both Adverbial Ability tests wholly and dimensionally.

These significant differences may be attributed to the implemented IPT-based strategy. It was constructed upon the information processing theory with so many learning tasks and activities carefully selected, arranged, and integrated within the content and context. This context, accordingly, specified the roles of both the teacher (the researcher) and 
the learners (second year students) in the classroom. The result of Construction Ability development is consistent with those of Hernández (2006); Zi-hong (2010); Dehham (2015); Ngangbam (2016); Yilmaz and Dikilitas (2017); and Atashian and Al-Bahri (2018) who have recommended systematic and explicit instruction of EFL adverbials and for raising learners' awareness in the meanings and functions of adverbials in EFL writing.

Moreover, the results of Placement Ability development is consistent with those of Al Fadda (2012); Farooq (2012); Lei (2012); Garner (2013); Leedham and Cai (2013); Dehham (2015); Ngangbam (2016); and Rutledge and Fitton (2015) who have highlighted the importance of teaching EFL learners adverbials placement to elaborate their writing skills and rhetorical awareness. Finally, the results of the overall ability developments is consistent with those of Garner (2013); Liu (2014); Sheikhani and Abdollahi-Guilani (2017); and Atashian and Al-Bahri (2018) who have recommended that certain and ultimate problematic adverbial aspects already diagnosed have to be addressed and developed.

Briefly, the strategic teaching procedures based upon information processing theory brought about strategic teaching and strategic learning in which the teacher (the researcher) was no longer lecturer or information provider and the learners (the second year students) were no longer active listeners and/or passive speakers. On the other hand, the teacher was just a coach, facilitator, guide, feed-back provider, and a participant in arranging the teaching-learning environment. In addition, the learners were strategic learners, active speakers, tasks executives, activities performers, production participants, IP practitioners, trainers, trainees etc. To sum up, IPT-based classroom turned learning environment from being teacher-centered to be learner-centered, through which the learner could produce oral/written language including the targeted adverbials) and develop his/her other grammatical abilities and awareness (knowing about knowledge). 
Through IPT-based strategic teaching/learning procedures, students worked individually, together in pairs or in small/large groups to achieve shared learning goals, i.e. getting a grammatical content, producing oral/written language, using it, and raising their linguistic awareness simultaneously. Thus, their learning accelerated, their engagement activated and improved, their communication sustained, and their awareness raised agreeing with the opinions of Wolfe (2010); Miller (2016); Schunk (2016); and Zhou and Brown (2017) who have confirmed the blossoming and promising potential role which the suggested IPT- based strategies can accomplish within EFL language classroom.

\section{Conclusion and Pedagogical Implications}

In the light of the statistical analysis of the results and their discussion, the researcher came up with the following conclusions: teaching EFL Adverbials ability in isolation from other parts of speech deliberately through specific instructional strategies brings about valuable learning outcomes. The students involved in the sample achieved progress in their ability to construct and place English adverbials. Consequently, providing EFL students with opportunities and materials through integrating cognitive activities and tasks with a linguistic content yields dual learning outcomes. It helps them get the targeted content in an interesting way and communicate/interact during getting it and using it at the same time. This leads, finally, to a long-term effect of language learning.

Accordingly, information processing theory is of great predicative potential and promising contribution in EFL teaching and learning. It is a mentally-based approach; it is a learner-centered approach which mentally programs the learner's mind to encode and decode the targeted language content to be learned in some learning activities and tasks urging students to systematically communicate/participate and accordingly learn; and then, no learning without communication/participation. The IPT-based activities and tasks are so beneficial; they provide a lot of alternatives and choices rather than one 139 
choice, and they enhance the quality of teaching-learning process. For these reasons, teachers should adapt and implement them to suit the characteristics of their teaching situation. Various techniques and activities based on IPT provide the students with the opportunity to use various kinds of learning skills and styles, i.e. VAK (visual, auditory and kinesthetic), in many effective ways. They also regularly trigger students' non-conscious mind and provide them with full opportunities to further use it in an appropriate way. By making use of such techniques and activities, teachers can bring variety of learning tasks and activities into classrooms, and thus, raise awareness and enhance motivation.

Finally, the present study has many pedagogical implications which are beneficial for both teachers and learners. Some implications derived from applying information processing theory are also very important for the teacher to consider. Teachers should train themselves to be process-oriented teacher and train their students to be processoriented learners in order to get their teaching goals best achieved. They should hold some brainstorming workshops and training sessions to give their students explicit information about new approaches or methods of teaching. In addition, they should train students to be flexible outcomeoriented learners and to control and modify the language input to get the prescribed targeted language goals achieved. They also should help students to identify their (preferable) learning styles to purposively direct their learning processes. Again, they should direct students to discover their mental processes beyond their language behavior and linguistic choices in order to orient and modify them continuously.

To sum up, Teachers should upgrade their knowledge about English grammatical (syntactic) problems and difficulties facing their students in order to target them. They should coach their students to create their own syntactic (dis)associations between their mother tongue (Arabic) syntax and that of English. Also, they should pay attention to syntactic clustering hypothesis which view language as a hieratical of skills should be the teachers focus in syntactically-oriented teaching practices. Every now and 
then, teachers should provide their students with different formats of learning tasks and activities to elicit English syntactic output as much as they can. It is also their responsibility to train their students to avoid overgeneralizing use of some easy syntactic features.

\section{Recommendations of the Study}

- In the light of the previous results and the pertinent literature, the researcher provided the following recommendations:

- Teacher preparation programmes should include explicit treatment of English adverbials concerning their construction and placement.

- Teacher preparation programmes should systematically integrate English adverbials with writing tasks and activities.

- EFL evaluation (formal tests and examinations) should include parts separately evaluating different types and aspects of English adverbials.

- EFL major students should receive deliberate training on IPT to become able to intentionally optimize all of its techniques because they already use some of them in their daily teaching-learning practices.

- Other instructional strategies or programmes based on IPT should be designed for and taught to EFL learners.

- Grammatical competence should be paid more attention and improve through new cognitive theories and approaches because the core of grammar is the logical mathematical thinking.

- Strategic competence should be paid more attention. EFL classrooms should be a theatre of strategy training or even instruction. It should be an urgent duty of the teacher to instruct his/her students to use strategies in their learning. That's to say, they should monitor their learning and follow specific systematic steps that better help them achieve progress in any of language domains.

- More attention should be paid for /to enriching EFL classrooms with various and multi-level activities and tasks integrated and interwoven within the learning process. 


\section{References}

Ahamed, F. (2016). An investigation of writing errors of Saudi EFL university students. International Journal of Social Science and Humanities Research, 4(2), 189-211.

Al-Fadda, H. (2012). Difficulties in academic writing: From the perspective of King Saud University postgraduate students. English Language Teaching, 5(3), 123-130.

Al Karazoun, G. (2016). A linguistic analysis on errors committed by Jordanian EFL undergraduate students: A case of news headlines in Jordanian newspapers. English Language Teaching, 9(8), 170189. Retrieved from: http://dx.doi.org/10.5539/elt.v9n8p170

Atashian, S., and Al-Bahri, K. (2018). Towards Arab students' grammatical errors in academic writing and their perceptions. Arab World English Journal (AWEJ). Proceedings of 1st MEC TESOL Conference 2018. https://dx.doi.org/10.24093/awej/MEC1.10

Baddeley, A. D. (2001). Is working memory still working? American Psychologist, 56(11), 851.

Bigus, J (2011). Reflection on Behaviorism. New York: Harper Collins.

Carter, R., and McCarthy, M. (2006). Cambridge grammar of English. Cambridge: Cambridge University Press.

Crystal, D. (2003). The Cambridge encyclopedia of the English language $\left(2^{\text {nd }}\right.$ ed.). Cambridge: Cambridge University Press.

David, L., (2015). "Information Processing Theory" in Learning Theories, Retrieved from: https://www.learningtheories.com/information-processing-theory.html 
Dehham, S. (2015). Errors made by Iraqi EFL college students in using adverbs of frequency. Journal of Literature, Languages and Linguistics, 17, 32-41.

Delfitto, D. (2006). Adverb classes and adverb placement. In M. Everaert and H.van Riemsdijk (Eds.), The Blackwell companion to syntax (pp. 83-120). Malden, MA: Blackwell Publishing.

Dörnyei, Z. (2009). The psychology of second language acquisition. Oxford, UK: Oxford University Press.

Farooq, M. (2012). Opinion of second language learners about writing difficulties in English language. A research Journal of South Asian Studies, 27, 183-194.

Folse, K. (2012). Clear grammar 2: Keys to grammar for English language learners. ( $2^{\text {nd }}$ edition). Michigan: University of Michigan.

Gholami, P., and Tahriri, A. (2017). Peer scaffolding in an EFL writing classroom: An investigation of writing accuracy and scaffolding behaviors. RELP, 5(2), 147-166.

Gnanaseelan, J. (2016). The taxonomy of the functional and structural uses of adverbs in business letter writing in English. International Journal of Applied Linguistics \& English Literature, 5(5), 39-48.

Güneş, H. (2017). A corpus-based study of linking adverbials through contrastive analysis of $\mathrm{L} 1 / \mathrm{L} 2 \mathrm{PhD}$ dissertations. International Journal of Curriculum and Instruction, 9(2), 21-38.

Hernández, M. (2006). The position of adverbs in English: Trying to solve a major problem most language learners usually face. Filologiay Linguistica, 32(1), 271-285. 
Hewings, M. (2005). Advanced grammar in use: A self-study reference and practice book for advanced learners of English ( $2^{\text {nd }}$ ed.). Cambridge, UK: Cambridge University Press

Kako, E. and Wagner, L. (2001). The semantics of syntactic structures. Trends in Cognitive Sciences, 5(3), 103-108.

Kian, S. and Gorjian, B. (2018). Effects of input enhancement cues on EFL learners' intake of English grammar: The case of connectors. RELP, 6(1), 39-55.

Khomeijani, A., and Faryabi, F. (2017). The role of self-regulated learning capacities in Iranian EFL undergraduates' argumentative writing task performance. RELP, 5(2): 203-222.

Kuningas, J. and Leino, J. (2006). Word orders and construction grammar. Sky Journal of Linguistics, 19, 301-309.

Leedham, M., and Cai, G. (2013). Besides... on the other hand: Using a corpus approach to explore the influence of teaching materials on Chinese students' use of linking adverbials. Journal of Second Language Writing, 22(4), 374-389.

Lei, L. (2012). Linking adverbials in academic writing on applied linguistics by Chinese doctoral students. Journal of English for Academic Purposes, 11, 267-275.

Liu, G. (2013). On the use of linking adverbials by Chinese college English learners. Journal of Language Teaching and Research, 4(1), 149-155.

Liu, G. (2014). Investigating Chinese college learners' use of frequency adverbs: A corpus-based approach. Journal of Language Teaching and Research, 5(4), 837-843. 
Lutz, S., and Huitt, W. (2003). Information processing and memory: Theory and applications. Educational Psychology Interactive. Valdosta, GA: Valdosta State University. Retrieved from http://www.edpsycinteractive.org/papers/infoproc.pdf

McLeod, S. A. (2009). Short term memory. Retrieved from www.simplypsychology.org/short-term-memory.html

Miller, P. H. (2016). Theories of developmental psychology. ( $6^{\text {th }}$ ed.). New York, NY: Worth Publishers.

Murphy, R. (2015). English grammar in use (4 ${ }^{\text {th }}$ ed.). Cambridge: Cambridge University Press.

Ngangbam, H. (2016). An analysis of syntactic errors committed by students of English language class in the written composition of Mutah University: A case study. European Journal of English Language, Linguistics and Literature , 3(1), 1-13.

Rutledge, J. and Fitton, Z. (2015). Teaching ESL students' adverb position to develop rhetorical emphasis. Linguistics Portfolios, 4(12), 122-129.

Samanian, S., and Roohani, A. (2018). Effects of self-regulatory strategy development on EFL learners' descriptive writing and reflective thinking. RELP, 6(1), 95-116.

Sawalmeh, M. (2013). Error analysis of written English essays: The case of students of the preparatory year program in Saudi Arabia. RELP, 14(40), 1-17.

Schunk, D. H. (2016). Learning theories: An educational perspective ( $7^{\text {th }}$ ed.). Boston, MA: Pearson.

Swan, M. (2006). Practical English usage ( $3^{\text {rd }}$ ed.). Oxford: Oxford University Press. 
Tallerman, M. (2011). Understanding syntax ( $3^{\text {rd }}$ ed.). London: Hodder Education.

Wiersma, W. and Jurs, S. (1985). Educational measurement and testing. Boston: Allyn \& Bacon.

Wolfe, P. (2010). Brain matters: Translating research into classroom practice

( $2^{\text {nd }}$ ed.). Alexandria, VA: ASCD.

Y1lmaz, E. and Dikilitas, K (2017). EFL learners' uses of adverbs in argumentative essays. Novitas-ROYAL (Research on Youth and Language), 11(1), 69-87.

Yong-Yae., P. (2013). How Korean EFL students use conjunctive adverbials in argumentative writing. English Teaching, 68(4), 263-284.

Zaki, M. (2010). The development of fluency, syntactic complexity, and grammatical accuracy in oral presentations: A case of Egyptian EFL learners (MA Thesis). English Language Institute, American University in Cairo.

Zhang, B. and Koller, T. (2015). Adverbial phrase placements in L1Chinese ESL learners' writing. Linguistic Portfolios, 4(9), 100-107.

Zi-hong, Z. (2010). The syntactic positions of adverbs and the second language acquisition. Sino-US English Teaching, 7(9), 48-54.

Zhou, M., and Brown, D. (2017). Educational learning theories ( $2^{\text {nd }}$ ed.). Education Open Textbooks. Retrieved from https://oer.galileo.usg.edu/education-textbooks/1 